\title{
Research in cement and concrete over 40 years: experiences and lessons for the future
}

\author{
Mark Alexander \\ Yunus Ballim
}

Mark Alexander

Concrete Materials \& Structural Integrity Research Unit,

University of Cape Town, South Africa

Yunus Ballim

School of Civil Engineering, University of the Witwatersrand,

Johannesburg, South Africa

Corresponding author: Mark Alexander, mark.alexanderДuct.ac.za

https://doi.org/10.5592/CO/FTCE.2019.08 


\section{Research in cement and concrete over 40 years: experiences and lessons for the future}

\section{Abstract}

The paper traces the research trajectories of the authors over a period of about 40 years, during which time they have been actively involved in cement and concrete research in South Africa. Several focus areas are selected and presented, with an emphasis on industrial applications and inherent research lessons. The focus areas discussed, representing a selection of our work, include durability in reinforced concrete (RC) structures, corrosion in cracked and uncracked RC beams, heat and temperature development in large concrete masses, and biogenic acid attack on concrete sewers. The importance of industry-academic collaboration is highlighted, and it is shown how this has permitted much of the work to be adopted directly or indirectly by industry. Lastly, some generic research lessons are described.

Key words: research framework; durability; concrete materials; deterioration; concrete research

\section{Istraživanja cementa i betona tijekom 40 godina: iskustva i pouke za budućnost}

\section{Sažetak}

Rad prati istraživačke putanje autora u razdoblju od približno 40 godina, tijekom kojih su aktivno provodili istraživanja cementa i betona u Južnoj Africi. Odabrano je i predstavljeno nekoliko područja, s naglaskom na industrijskim primjenama i lekcijama proizašlim iz istraživanja. Razmatrana područja, koja predstavljaju dio našeg rada, uključuju trajnost armiranobetonskih građevina, koroziju u armiranobetonskim gredama $s$ pukotinama i bez njih, razvoj topline i temperature kod masivnih betona i napad biogenih kiselina na betonske kanalizacije. Istaknuta je važnost suradnje industrije i znanosti, te je prikazano kako je takva suradnja omogućila da se velik dio istraživanja izravno ili neizravno primijeni u praksi. $\mathrm{Na}$ kraju su opisane neke generičke lekcije proizašle iz istraživanja.

Ključne riječi: istraživački okvir, trajnost, betoni, degradacija, istraživanja betona 


\section{Introduction}

Delivering this lecture at the University of Zagreb, where the Faculty of Civil Engineering is celebrating its centenary year in 2019 , offers a unique opportunity to reflect on a long road walked in concrete research by the authors, whose careers have jointly spanned a more modest 40 years. But first, we wish to acknowledge the tremendous contributions of the Faculty of Civil Engineering's Department of Materials at the University of Zagreb; the impressive example, also over many years, of the Zagreb team led by Prof Dubravka Bjegović is truly inspiring, and Dubravka and her colleagues are indeed to be congratulated and commended on this wonderful occasion!

Of course, the theme of this event is "Future Trends in Civil Engineering", and so why take a topic on 'experiences and lessons' from past research? The answer is simple: we cannot confidently go into the future without understanding from where we have come, and we need to take the lessons of the past into the future. Reflecting on past experiences can help point the way to future actions and directions.

Returning to our own journey, both authors have studied and taught at the University of the Witwatersrand in Johannesburg, South Africa, an eminent African university and research institution. The first author had the good fortune to supervise the Masters and Doctoral work of the second author, and this led to a life-long research association, and indeed friendship, that has endured, just as durable concrete should do!

We wish to take some focus areas of our work, and in addition to presenting some of the important research findings, to dwell also on the lessons learnt from a research perspective.

\subsection{Background}

South Africa has a long-standing and well-established cement and concrete sector, which historically has enjoyed support and stimulation for research and education. Drawing on the benefit of this support, local researchers have made significant contributions to developments in the science and technology of cement and concrete materials, aiming at a better understanding of these materials and their use in construction. For example, early work on the hydration of ground granulated blast furnace slag and its use as a supplementary cementitious material dates back to the 1950s and early 1960s [1], with the consequence that GGBS has been used in concrete in South Africa now for nearly 60 years. Other pioneering work has been in understanding the mechanisms of alkali-silica reaction (ASR) [2], which led to the well-known accelerated mortar bar test method for assessing the alkali susceptibility of concrete aggregates, now embedded in ASTM CI260 (reflected in the local standard SANS 6245). Some of the earliest work on the effects of ASR on structural behaviour was also carried out in South Africa [3].

This situation has continued to the present, allowing sustained research contributions to emanate from our own work and that of others. Since the 1990s, we have worked 
in the cement and concrete research groups at the University of Cape Town and the University of the Witwatersrand, respectively. This has allowed research collaboration across institutions, with an important outcome being the wide range of geographic and disciplinary collaborations that have emerged and continue to be sustained. Of course, all this work would not have been possible without the contributions of highly intelligent and industrious research students, many of whom have, in their own right, become major players in the concrete research arena, and they are duly acknowledged in the paper.

This paper explores first the research framework that has guided our work over the years, and then covers four broad, interrelated areas of our collaborative research: durability in reinforced concrete $(R C)$ construction in South Africa and the subsequent unique development of a system of early-age durability 'indexes' to control the quality and improve the long-term durability of RC structures; aspects of steel corrosion in RC members, both cracked and uncracked, and the consequent structural behaviour of such corroded members; heat and temperature development in large concrete sections, using an easily-manipulated computation tool that takes into account the 'maturity heat function' for concrete; and biogenic acid corrosion of concrete sewer pipes.

Throughout this range of research, an important focus has been to develop and continually refine methods for predicting the performance of concrete, as useful instruments for design and construction engineers, while also seeking to understand the fundamental mechanisms that explain the behaviour of the complex material that is concrete. This has required structured local and international collaborative partnerships with materials scientists in disciplines such as chemistry, physics, geology and electro-chemistry, which have enhanced our own understanding and contributions.

This review paper draws on similar recently compiled reviews of our work [4], [5], [6]. The authors also acknowledge the contributions of colleagues and research students over the years, some of whose work is mentioned below.

\section{Framework for concrete (durability) studies}

Much of our work relates to concrete deterioration and durability. From the outset, we argued that durability is not an inherent material property of concrete, in the way that strength or elastic stiffness are, because durability encompasses concrete as a materials system interacting with an exposure environment that varies in its aggressiveness to concrete. In the early stages of our work, this concept of "durability" led to the development of a framework to integrate and bring coherence to the wide field of durability research. Figure I shows the philosophical framework that we developed and adopted for our research in durability (adapted from the first one presented in [7]). Its starting point is the need to characterise or 'index' the concrete, as a material system and as a composite material, for its ability to resist the deteriorating effects of the exposure environment. This indexing is critical in 
RC for the reinforcement cover zone, which is the first line of defence in protecting the underlying steel and structural core. The indexes must also be reproducible measures that can be reliably referenced to a performance scale to indicate the likely durability performance of the concrete. These indexes are further discussed in the next section.

Framework for Concrete Durability Research - South African Approach

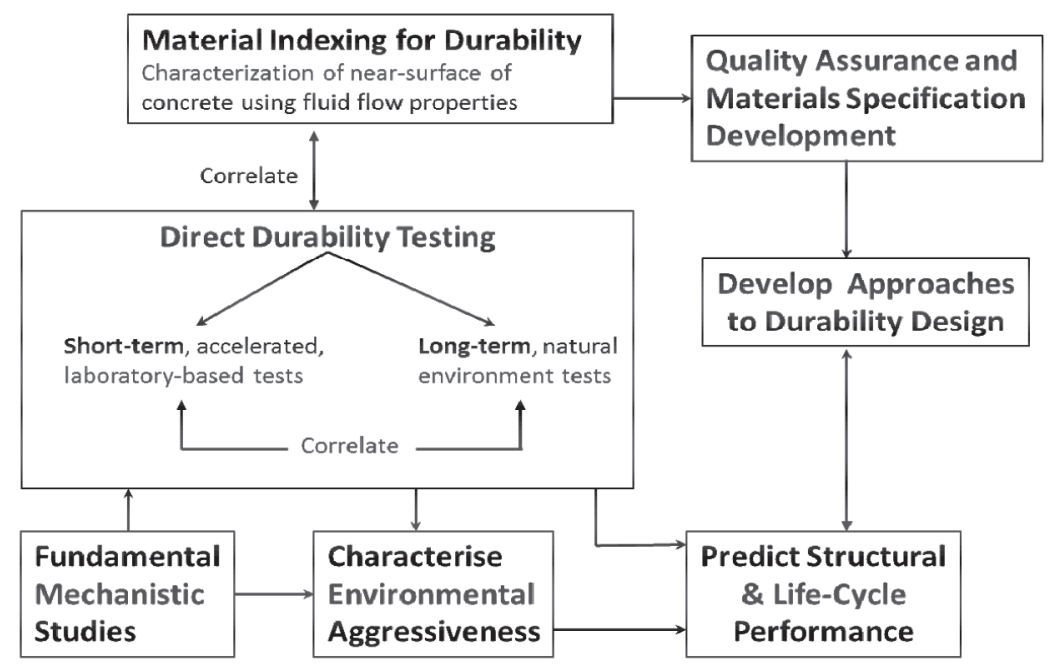

Figure I. Guiding framework for durability research and development in the South African context (adapted from [7])

A deeper knowledge of the fundamental mechanisms of deterioration in different aggressive environments is also required to better understand the concrete-environment interactions, and to characterise the nature and degree of environmental aggressiveness. This is essential for developing predictive models for structural and life-cycle performance of concrete in its environment. The primary objective of the framework approach to durability and deterioration of concrete is to develop increasingly reliable approaches to durability design of concrete structures. The understandings that emerge from the research must give greater meaning to the use-value of the durability indexes in a manner that positively influences specifications and structural design codes, and so provide designers and constructors of concrete infrastructure with the tools needed to ensure improved durability. The durability indexes must also be correlated with the results of direct durability testing, both long-term tests in natural aggressive environments, and accelerated laboratory-based aggressive environments (see Figure I). This allows the durability index performance scale to be developed, from which quality assurance schemes and concrete performance specifications can be developed, with durability indexes as early-age control parameters for the quality of construction. 
This schema is commended to researchers, as a cognitive framework that helps organize and interpret information, ensuring coherency and continuity in the work over time. As will be seen in the following sections, these durability indexes are a pervasive and useful part of all our work.

\section{Durability in reinforced concrete structures}

In the early 1990s, major problems began to arise with lack of durability in RC structures in South Africa, notably water-retaining and transport infrastructure. A workshop was convened of local and international researchers to consider this problem, from which came a major programme on improving durability of concrete construction. This led in time to the so-called 'Durability Index Approach' for controlling corrosion in RC structures, introduced in the preceding section.

\subsection{Development of the Dl approach}

The durability research programme conceptualised, developed, and implemented the durability index (DI) approach [8], [9], [I0], [I I]. Three 'durability index' tests (oxygen permeability index test $(\mathrm{OPI})$, chloride conductivity index test $(\mathrm{CCl})$, and water sorptivity test (WSI)) were developed early in the work, which facilitated major progress in the early years. Without these tests - now incorporated in South African National Standards [12], [13], [14] - the entire scheme in Figure I would have floundered. The overall result has been an integrated approach based on the measurement of Dls, permitting material characterisation, site quality control, performance-based specifications, service life prediction, and durability analyses. A photograph of the OPI test arrangement is given in Figure 2.

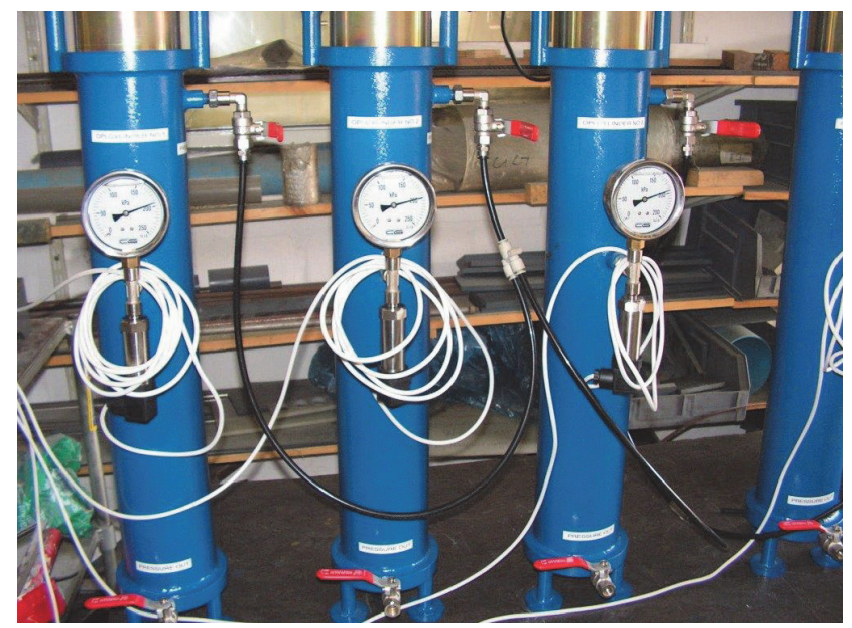

Figure 2. A set of oxygen permeability (OPI) rigs with pressure transducers and pressure gauges 
The DI tests have the major aim of characterising the physical and chemical properties of the concrete cover, and thereby to control its properties. Each durability index is linked with a transport mechanism, i.e. gaseous permeation, water absorption, and ionic diffusion, and thus relates to a deterioration process. The three index tests are sensitive to material, processing, and environmental factors such as binder type, water:binder ratio, and curing, which influence durability in the long run. The tests can be thought of as measuring the potential of the concrete to fulfil certain durability criteria for the structure. The tests also provide reproducible engineering measures of the microstructure of concrete.

The tests had to be site- as well as laboratory-applicable, therefore requiring cheap, robust equipment, and relatively small specimens which could be cored from laboratory or site elements. Site-applicability was critical to assess the quality of asbuilt structures, for which 'bulk' laboratory specimens such as cubes were wholly inadequate. The problem of in-situ measurement of concrete durability properties was also recognised early, and it was decided to extract small diameter $(70 \mathrm{~mm})$ cores that could be sliced into 25 - $30 \mathrm{~mm}$ thick discs, which could be preconditioned in the laboratory to ensure reliable and repeatable results, an industry requirement for acceptance of the tests. Note that many similar test methods have been developed by researchers around the world, each with their own advantages and limitations. Our work was strongly focused on our local context, for which we developed these test methods.

\subsection{Industrial applications}

The 'durability index approach', now standardised, has achieved broad acceptance and application in South Africa, and has been actively adopted by large national infrastructure bodies, such as the South African National Roads Agency SOC Ltd. (SANRAL). Local agencies have developed their own performance-based specifications using Dls. Experience with this approach in major construction projects has, in general, indicated improved quality of concrete construction and a much greater awareness of durability considerations in the concrete manufacturing and civil engineering industries. The approach has also, however, revealed situations where adequate potential durability has not been achieved in major concrete constructions. For example, Figure 3 shows OPI results, from a major road- and bridge-building contract, measured on actual structures built using the DI approach; it clearly indicates that different contractors achieved different outcomes, despite working to the same set of specifications and essentially using the same ready-mix supplier. This was one of the first occasions where we were able to show that it was possible, in actual construction, to characterise the quality of the construction processes. Recent work has concentrated on a hybrid scheme whereby structures are characterised in-situ using an NDT device such as the Torrent Meter, and if these results show possible problems with the quality, the semi-invasive OPI technique can be used, and this is showing good promise. [15], [16]. 

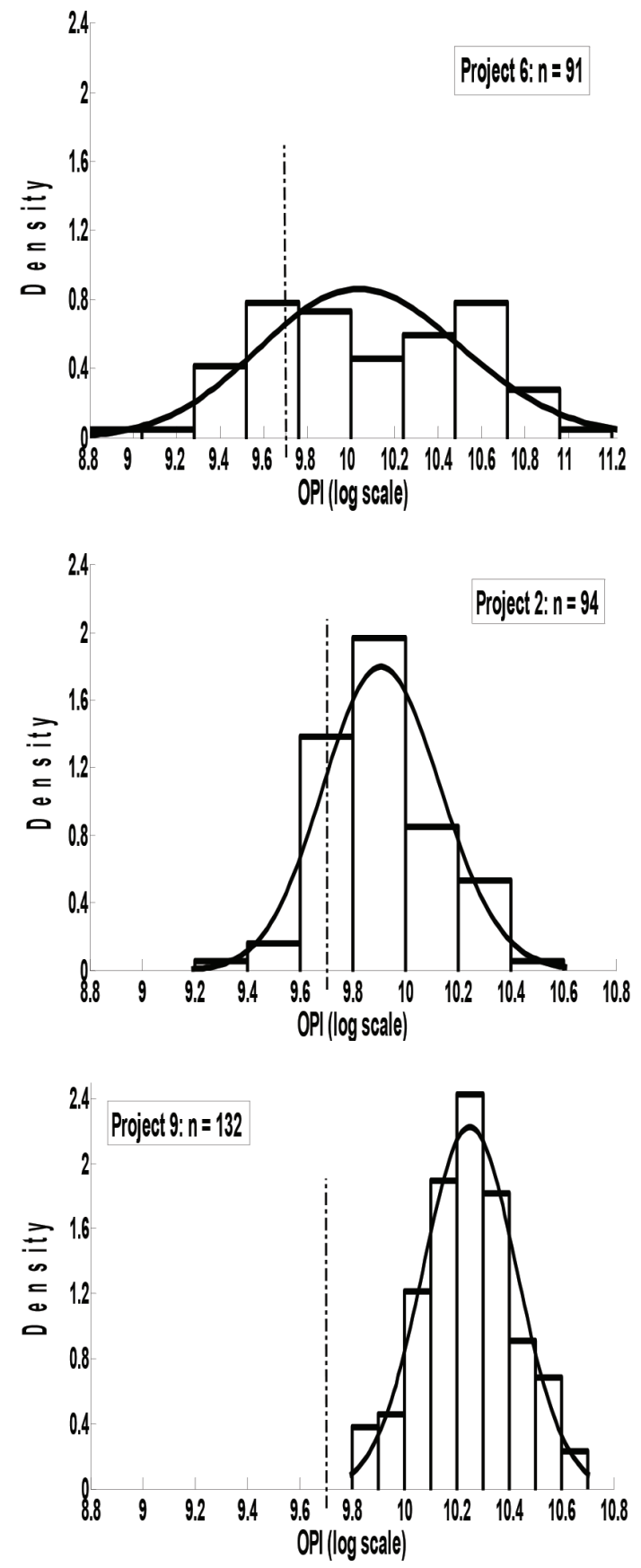

Figure 3. Oxygen permeability results from actual structures, showing variable construction quality [I7] 
In summary: the 'DI approach' is a powerful means for assessing potential durability of concrete, and finds practical application in site and laboratory situations and prediction models. This approach stresses material characterisation at an engineering level, and links the indexes to long-term performance. Materials and construction requirements can be related to environmental and other structural 'loads'. It breaks with ineffective durability design (e.g. prescriptive approaches), and provides the basis for a performance approach (which is an extensive topic not dealt with in the limited space here, but on which we have written extensively). The work is innovative by calibrating early-age indexes with later-age structural performance, which we expect will give reliable and robust prediction. South African concrete practice is at a stage of durability implementation that possibly equals or exceeds that elsewhere. An active programme of technology transfer and publication has generated acceptance for the approach, with consequent improved local practice.

\subsection{Research lessons}

The most valuable lessons from this work on durability indexes are the need for a philosophical framework; the importance of linking work to industry needs, at least for the needs of a developing country such as South Africa; also, the need to be persistent in getting the results of research accepted by industry, since this can be a very onerous process. On this last point, industry acceptance of the work was greatly facilitated by making the research available in the form of easy-to-read monographs giving the main findings (see Section 8. I. and weblink), which were presented at technology-transfer workshops with an industry audience; by regular interactions with the main industryplayers; and by visits and engagement on industry's major issues. The acceptance of the durability index approach to quality assurance by a major quasi-government roads authority (SANRAL) also gave impetus and 'respectability' to the research in the eyes of designers, constructors and concrete materials suppliers.

\section{Steel corrosion in reinforced concrete - cracked and uncracked}

\subsection{Background}

The work on corrosion of steel in RC structures grew naturally out of the overall concern with durability in RC structures, particularly in marine environments. It was informed by the realisation that, in many cases, the initiation period of corrosion in cracked RC members was very short in chloride environments, which implied that, for most service life prediction models, the life of the structure was essentially zero! Thus, the propagation period should be considered in service life assessment. The work also addressed more fundamental issues: influence of different binder types and crack widths on corrosion rates, correlation of laboratory and site studies of corrosion rate, and influence of wetting/drying cycles on accelerated corrosion. 
Laboratory and site-based studies were carried out, linked to the DI approach by incorporating the $\mathrm{CCl}$ as a key material prediction parameter, reflecting the combined influence of binder type and w/b ratio ('concrete quality'). The results showed conclusively the critical influence of crack width on corrosion rate, with even 'incipient' cracks having a marked influence - see Figure 4 - but also that with appropriate concrete quality, corrosion rates could be sufficiently controlled to ensure a reasonable service life of cracked members in chloride environments, Figure 5 .

The critical influence of wetting and drying cycles on accelerated corrosion rates was also appreciated, indicating that it is difficult to compare corrosion rate data across different researchers using different methods. This is illustrated in Figure 6, where a distinction emerges between 'high' and 'low' quality concretes in responding to different drying cycle durations.
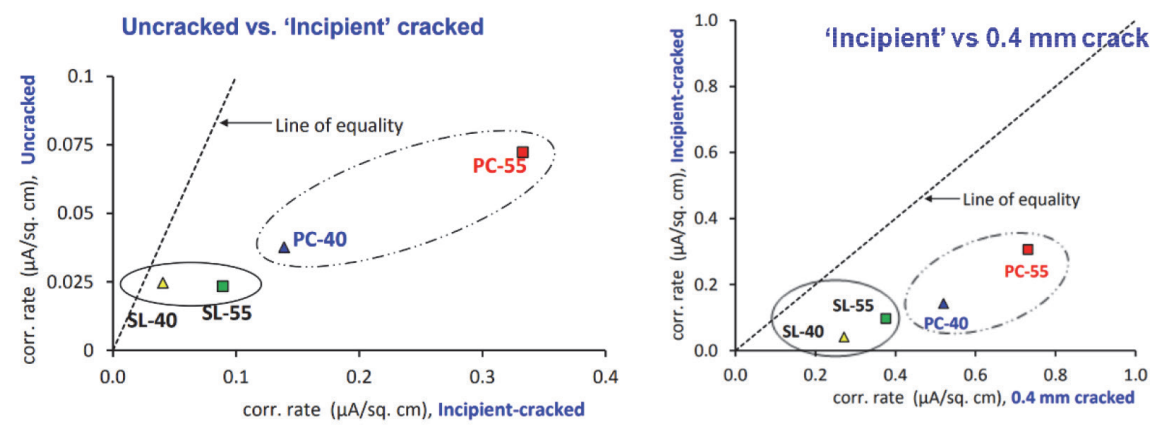

Figure 4. Influence of crack width on corrosion rate of steel in concrete lab specimens [18]

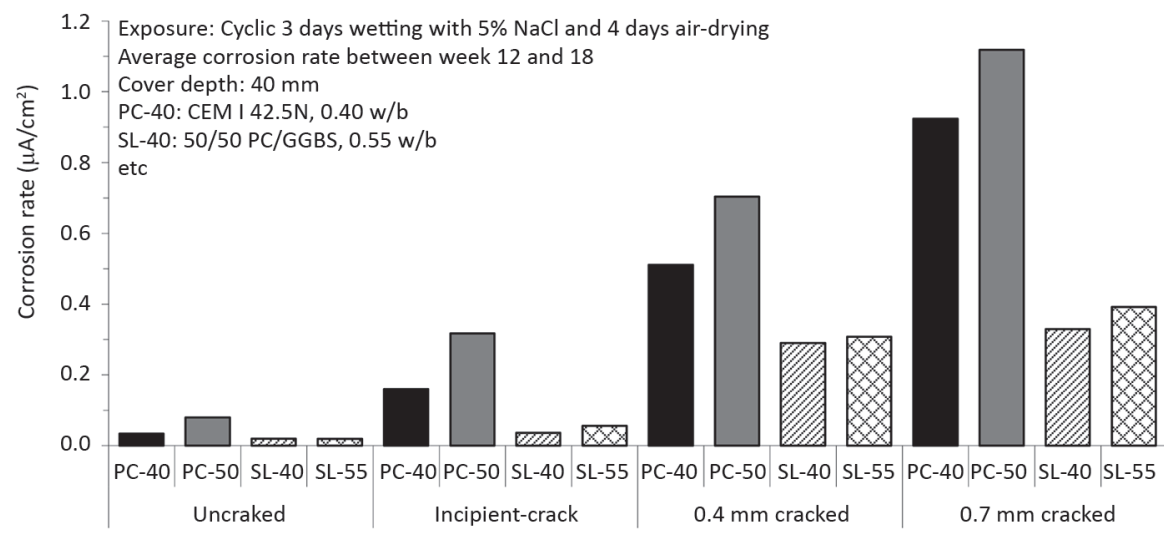

Figure 5. Corrosion rates $\left(i_{\text {corr }}\right.$ ) of laboratory specimens: influence of cracking, binder type, and $\mathrm{w} / \mathrm{b}$ ratio [19] 

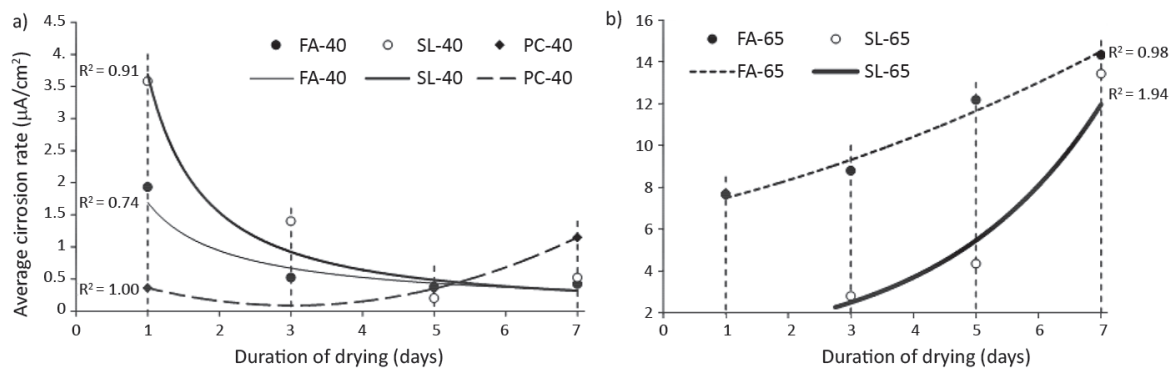

Figure 6. Effect of drying duration on corrosion rate in different concretes: a) "high" quality concretes; b) "low" quality concretes. All specimens subjected to I-day wetting, followed by various drying durations [20]

\subsection{Industrial applications}

Direct uptake of the research in this case was limited. Nevertheless, the work firmly established the imperative of using blended cements in marine (chloride) environments, due to a double benefit: substantial extension of the initiation period, and thereafter (largely resistivity) control of the corrosion rate. It also gave confidence to designers in using the correct range of materials. A corrosion rate model has been developed, but needs extension to site applications, since site-based corrosion rates were found to be substantially lower than laboratory-based values.

\subsection{Research lessons}

An important realisation early-on was the need to consider carefully the meaning of the results from laboratory-based studies, and applicability to the performance of actual structures in service. As an example, much of the laboratory work on the effects of reinforcement corrosion on deflection of RC structures was based on a sequential approach of inducing corrosion in the reinforcing steel of a laboratory RC sample and then subjecting it to a load to monitor deflections. However, in actual structures, the corrosion occurs while the load is sustained. Ballim et al. [2I] showed that under conditions of simultaneous load and corrosion, the deflections are significantly larger than in the case of sequential loading and corrosion. Their results, in comparison with those obtained by Cabrera and Ghoddoussi [22] using a sequential corrosion and loading arrangement, are shown in Figure 7.

These findings also point to the need for site-based studies to underpin and inform laboratory studies. Although not shown here, the corrosion rate data given earlier differed markedly from site-based corrosion rates, on specimens identical to the laboratory ones, but exposed in a 'real' environment. The site-based corrosion rates were substantially lower, implying the need to develop a realistic corrosion rate model.This confirmatory site work has always been a strong element in our research. 


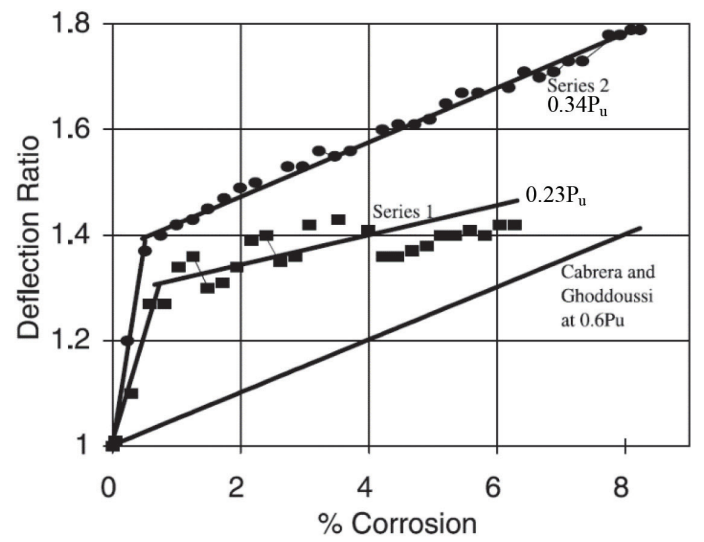

Figure 7. Laboratory studies of the effects of the extent of corrosion on deflection under simultaneous load and corrosion (Series I and 2) [2I] compared with sequential corrosion and loading [22]

\section{Heat and temperature development in large concrete masses}

\subsection{Background}

Interest in research into the heat of hydration of cement and the potential for thermally-induced cracking of large concrete elements was largely stimulated by the construction of the Katse Dam in Lesotho, with the main dam wall comprising 2,3 million $\mathrm{m} 3$ of concrete with up to $70 \%$ of supplementary cementitious materials (fly ash).At the time of design and construction of the dam, the Witwatersrand University team had already developed a low-cost adiabatic calorimeter for measuring the heat of hydration of cement in a concrete mixture [23], to characterise the hydration features of cements from different manufacturing plants [24]. However, the important breakthrough came when we successfully developed a maturity approach to normalising the adiabatic heat-rate curve for a binder in a manner that made the function independent of the time-temperature history of the concrete [25]. Without this, computational solutions are not an option because of the infinite combinations of time and temperature that are possible in an actual structure, and we would not be able to develop the models necessary for practising engineers and contractors to do 'first-pass' checks on heat generation and the likelihood of thermal cracking in large sections. The normalised heat-rate curve allows a single heat-rate function to be applied to all parts of a concrete element, regardless of the different stages of hydration due to different temperature conditions.

To illustrate, Figure 8 (a) shows adiabatic calorimeter results for the same Portland cement concrete but with the tests started at three different temperatures. The different heat-rate curves emphasise the significant influence of the time-temperature 
history on the heat-rate function for concrete. Figure 8 (b) shows that this can be normalised if the time scale is expressed in Arrhenius maturity units - in this case, the equivalent time at $20^{\circ} \mathrm{C}$ - and the heat rate is expressed as 'joules per maturity second'. Figure 8 (c) shows that the Nurse-Saul function is not suitable to account for the time-temperature history and, by implication, is not a suitable function to describe the development of hydration and engineering properties of concrete.
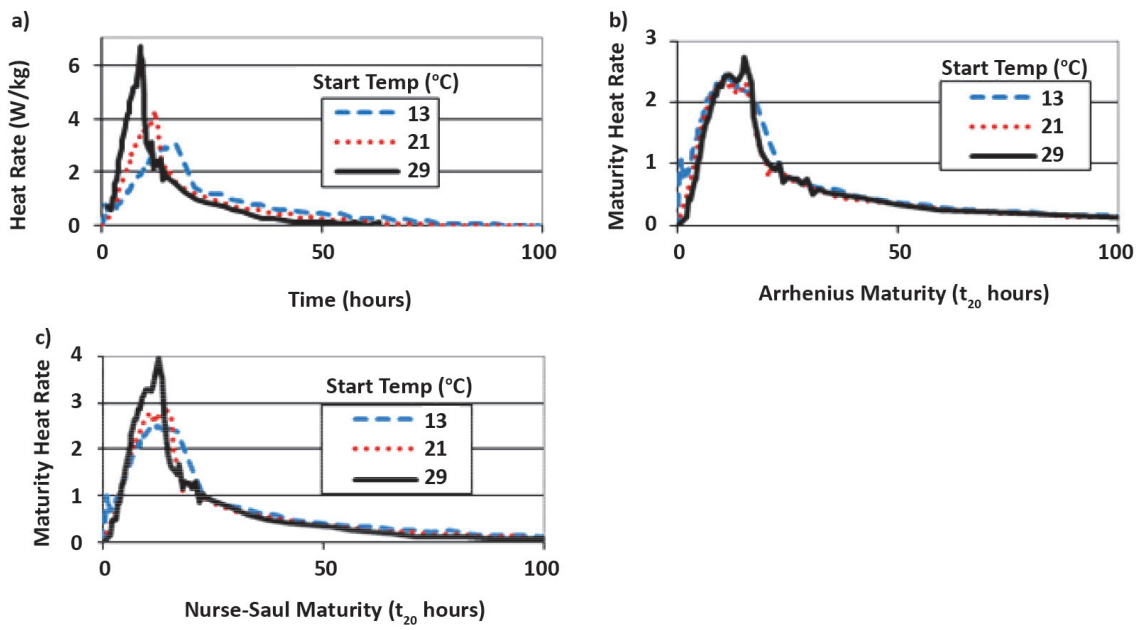

Figure 8. Normalisation of the heat-rate function: a) adiabatic results obtained for three different starting temperatures, b) results expressed in Arrhenius Maturity form, c) results expressed in Nurse-Saul Maturity form

This normalisation approach allows computational modelling of temperature development in actual concrete structures, because the heat-rate function at any point in the structure at any time after casting can be determined from:

$\left(\frac{\partial q}{\partial t}\right)_{x, y, z, t}=\left(\frac{\partial q}{\partial M}\right)_{x, y, z, M} \cdot\left(\frac{\partial M}{\partial t}\right)_{x, y, z, t}$

Where:

$\left(\frac{\partial q}{\partial t}\right)_{x, y, z, t}-$ is the actual heat rate at point $(x, y, z)$ in the concrete element at time $t ;$ $\left(\frac{\partial q}{\partial M}\right)_{x, y, z, M}$ - is the normalised maturity heat-rate at point $(x, y, z)$ at maturity level $M$; $\left(\frac{\partial M}{\partial t}\right)_{x, y, z, t}-$ is the rate of change of maturity at point $(x, y, z)$ at time $t$. 
A computational model (run from a simple Excel platform) was developed, using the measured adiabatic heat-rate profile as input, to predict the temperature development throughout a large concrete structure [24]. The model accounts for a wide range of materials and construction process variables. Figure 9 (a) shows an example of model output, specifically the significant effect of supplementary cementitious materials such as fly ash (FA) and ground granulated blastfurnace slag (GGBS) in reducing the maximum core temperature in a $4 \mathrm{~m}$ high $\times 3 \mathrm{~m}$ wide concrete block with $300 \mathrm{~kg} / \mathrm{m}^{3}$ of binder. The figure also shows the cyclical variation in the temperature difference between the centre of the concrete and the surface exposed to ambient temperature variations. Figure 9 (b) shows model predictions of the effects of reducing the initial casting temperature of the concrete in the construction process.
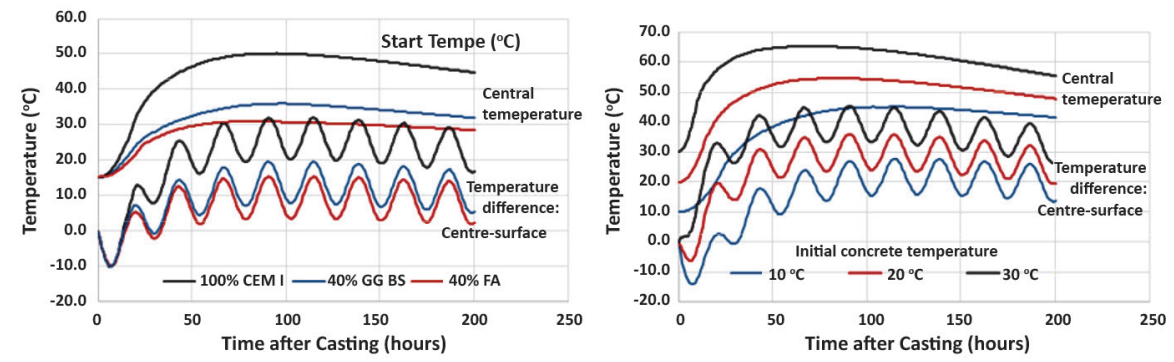

Figure 9. Modelled results of the effects of (a) FA and GGBS, and (b) varying the initial concrete temperature, on the central temperature and temperature differences, in a $4 \mathrm{~m}$ wide $\times 3 \mathrm{~m}$ high concrete block

\subsection{Industrial applications}

The main value of the work in heat flow and temperature prediction in large concrete structures has been the development of a more rational approach to selection of concrete mixture parameters when thermal cracking is a concern. The temperature prediction model that emerged from this work has been used in a number of projects in South Africa and abroad to provide a guide to the most suitable mixture design and construction method to minimise the risk of thermal cracking, at the design or pre-construction stages of the project. We have also made the model available to users in the concrete construction community at no cost.

Much of the industrial applications of the model have been in preliminary design of concrete dam walls and related concrete structures. However, the model has also been used to consider the possibility of cracking in a relatively thick concrete wall at the oncology unit of a hospital, where the concern was around radiation containment. The model was also used in consideration of the temperature rise in a continuously poured, thick concrete floor slab, with high cement content necessary for early strength. 


\subsection{Research lessons}

The development of the adiabatic calorimeter, together with the maturity normalisation approach, has allowed us to determine a heat 'signature' for a particular binder type for use in concrete. The next stage will be to better understand the effects of variations in binder chemistry and morphology on the heat-rate profile and the possibility of designing binders for particular heat characteristics. This is ongoing work and we are particularly interested in the effects of supplementary cementitious materials in modifying the heat response of hydrating binders.

In the development of the temperature prediction model, further research and development is required to better define the boundary conditions. This will require the model to better account for variations in climatic conditions over a period of a few days, the effects of partial solar radiation, and the effects of near-surface drying resulting in a decrease in the thermal conductivity of that zone of the structure.

\section{Concrete sewer pipes and biogenic acid attack}

\subsection{Background}

Corrosion of buried concrete sewer pipes is a pervasive problem in many countries, and costs are huge when sewer failures occur. This is true also of South Africa, where a large part of the large sewer pipe infrastructure stock is now approaching 40 - 50 years of age. With rapid urbanisation, large new drainage infrastructure needs to be built, and this will continue into the foreseeable future. Thus, the need arises of how to design new sewer systems for adequate corrosion resistance, and how to rehabilitate aged sewers for substantial life-extension.

The problem relates to the generation of sulphuric acid on the walls of a concrete sewer pipe by sulphide-oxidizing bacteria (SOB) - so-called biogenic acid attack - and the problem is not simply one of mineral acid resistance; the activity of the microbes must be understood and taken into account. The research question was therefore: which combinations of concrete materials (binders and aggregates) were most appropriate for South African sewer conditions, to resist biogenic acid attack? Could these be implemented industrially without major change to the existing manufacturing processes?

\subsection{Development of solutions}

Early research by the South African Council of Scientific and Industrial Research on aggregates for concrete sewers led to use of calcareous aggregates from the 1960s. This was followed by construction of, and studies in, the Virginia Experimental Sewer (VES), which is a live full-scale experimentation site, and which has yielded rich research information over a period of more than 25 years [26], [27], [28]. It has permitted developing improved models for predicting the response of concrete pipe materials, including different binders, to biogenic sewer corrosion, extending current 
models well outside the range of conventional materials, and better understanding of the phenomena.

For example, work on specimens exposed in the 'real live' sewer environment of the VES show the superior performance of CAC-based concrete compared to PC-based concretes - by factors of up to about 4 in terms of longevity of the pipe walls, as shown in Figure 10. Binders with higher calcium content and lower alumina content such as Portland cement-based (PC) binder systems experience greater corrosion than systems with higher alumina contents such as calcium aluminate cement (CAC) systems. The work also revealed the following:

- This higher corrosion rate in PC-based systems is attributed to (i) higher amounts of both $\mathrm{CH}$ and $\mathrm{C}-\mathrm{S}-\mathrm{H}$ which are consumed by the attacking acid to form gypsum, and later secondary ettringite $\left(\mathrm{C} 6 \mathrm{AS}_{3} \mathrm{H}_{32}-\mathrm{AFt}\right)$, and (ii) the cracking and spalling of the degraded matrix, due to loss of cohesion and the expansive pressure of ettringite formation.

- The higher alumina content of CAC-based mixtures yields an alumina gel with greater cohesion of the degraded layer, which partially protects the underlying sound layer and slows down the rate of attack.

- CAC systems also have higher neutralisation capacity than PC systems, due to the alumina gel component $\mathrm{AH}_{3}$, which becomes a major rate-controlling factor under biogenic acid attack in CAC systems.

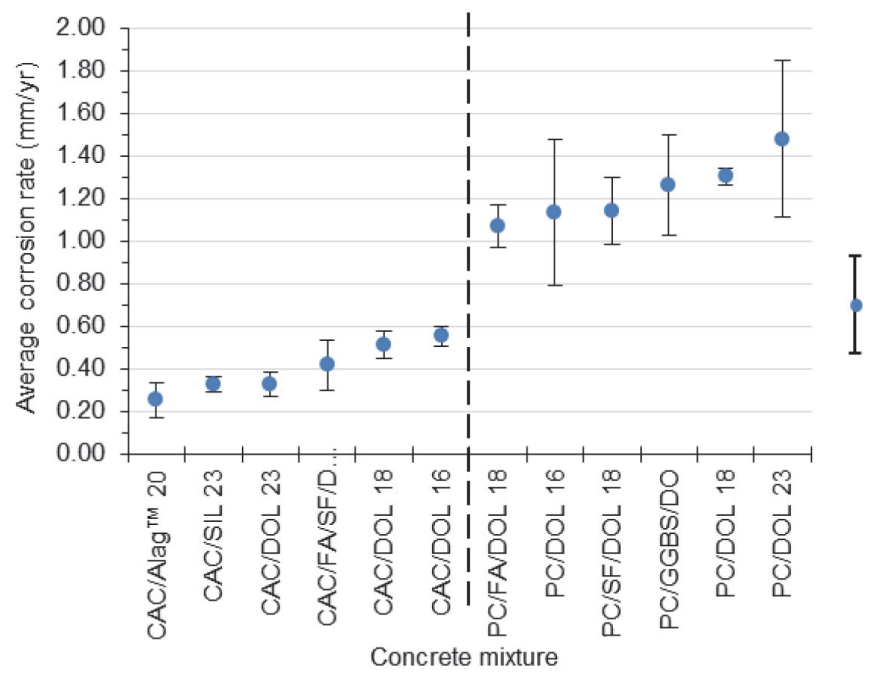

Figure 10.Average corrosion rates of PC- and CAC-based concrete mixtures subjected to biogenic H2SO4 for 127 months in a 'live' sewer [29]

The work also allowed the development of an improved 'Life Factor Method' (used in corrosion design of sewer systems) by incorporating the materials factors, covering a wider range of binders than before, so directly benefitting the industry - see Figure I I. 


\subsection{Industrial applications}

This work has led directly to improved pipe material selection such as calcareous aggregates and CAC liners, since industry could see the direct benefits of the work. This was assisted by the fact that part of the earlier work was sponsored by industry, but also because a member of our research team was an industrial consultant who was able to transfer the results directly to industrial practice. The improved model prediction now allows us to extend predictions to binders other than PC.

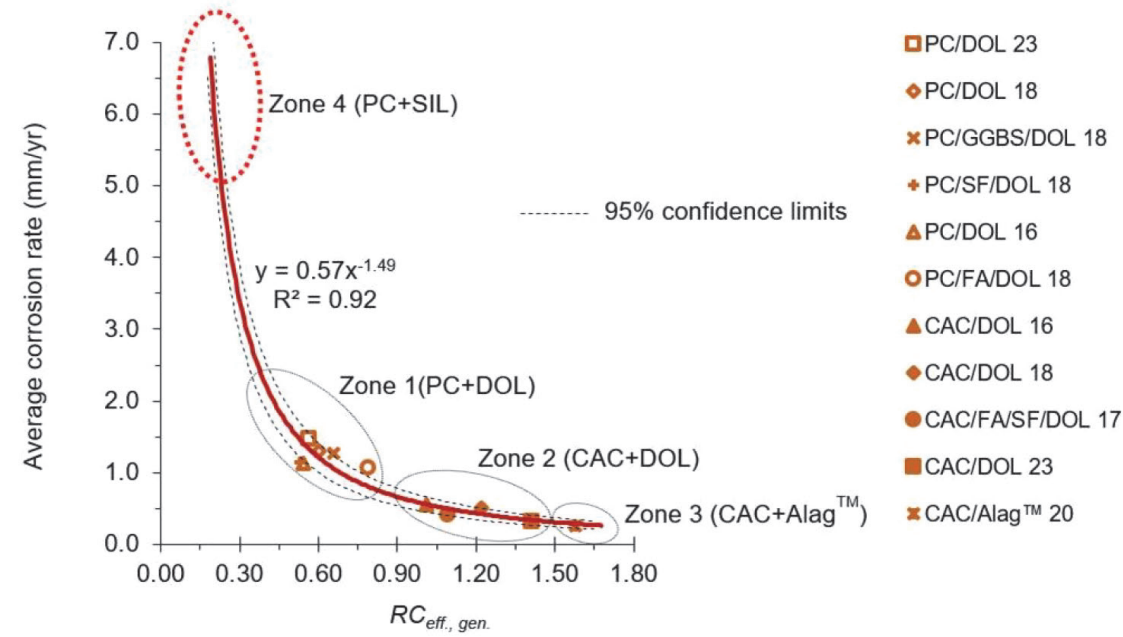

Figure I I. Extension of the LFM to a wide range of binders and aggregates, based on the VES studies by [30]

\subsection{Research lessons}

The main research lesson from this aspect of our work has been to again confirm the need for 'real' site-based experimental work, to gather data that can be used to calibrate other laboratory-based work and realistic materials models. Particularly in the complex environments in which many concrete structures have to operate, such work is essential in arriving at better understanding of the phenomena, and hence better ability to model such situations.

\section{Other aspects}

The research topics discussed above are a selection of our work over the years. Other research has involved characterising South African crushed aggregate sources to refine models for predicting deformations and deflections in concrete structures; 
time-dependent deformations to inform local and international models; alkaliaggregate reaction with work on monitoring structures suffering from AAR, thereby allowing extended lifespans of such structures without demolition (see earlier).

\section{Industry-academic research collaboration and funding}

The importance of a supportive cement and concrete industry, as partner to university-based research in sustaining the local contributions to research and development, is also important. The research teams in South Africa have enjoyed the benefit of a supportive industry that, up to now, has understood and appreciated the need for development of both concrete materials technology and human intellectual capacity to strengthen the industry and its contribution to technological and social development

Concrete researchers in South African have seldom had the luxury of undertaking much "blue sky" research, due to lack of large funding opportunities and a small number of researchers at any time. University researchers have long realised that, to sustain research funding, the outputs have also to address the problems faced by industry in the development and application of concrete materials. However, researchers have also retained their academic independence and, when necessary, have rather forfeited industry funding when the research agenda was too strongly dictated by industry. Nevertheless, over the years, the industry-university collaboration in South Africa has led to trust on all sides, firstly because industry had its problems addressed, and secondly because the research undertaken was of a quality that was acknowledged internationally (through journals, conferences, international collaborations, etc.). South African concrete researchers have consistently made useful contributions internationally, despite the disparities in the quanta of research funding locally and abroad. South Africa continues to be at the forefront of developments in concrete technology, due to the sustained research efforts mentioned, and also due to industry being open to international trends, often by being linked with large international consortia for major infrastructure projects.

\subsection{Technology transfer}

Communicating research findings to industry to encourage direct uptake is not easy. Academic papers, theses, and reports are largely opaque to industry. We addressed this by producing Monographs based on the research, and making these available to industry via different platforms - e.g. workshops, seminars, website, direct advocacy, etc. To date, nine Monographs have been produced, varying from the Durability Index approach to durability, to penetrating corrosion inhibitors, and steel corrosion. The full set can be accessed at: http://www.comsiru.uct.ac.za/con/downloads. 


\section{Future trends in civil engineering}

Future trends in civil engineering will depend on the particular sub-discipline, but undoubtedly, the major impact will be the implications and benefits of the so-called "4th Industrial Revolution". This will result, at least in developed countries, in much greater industrialisation of concrete production, automation, and so on. In developing countries, the focus is often on job creation in the construction sector, which might dictate retaining more conventional construction methods and materials; nevertheless, there will be niche applications of the latest technologies in various industrial segments. Our own experience is that it is possible for 'high-tech' construction to be done using labour-based methods. However, in the longer-term, concrete construction will move in the direction of greater industrialisation of production. Concrete as a material will face the following challenges: a much greater reduction of the carbon footprint; compulsory use of more waste and recycled materials; minimisation of resource use and site-wastage; 'de-materialisation' of the design and construction processes. Further major developments in new binders will occur, and these may impact structural design. As in the past, it is likely to be developments in the material that lead to advances in structural applications. Since the vast majority of concrete construction in coming decades will take place in the developing world, where great needs exist for basic shelter and infrastructure, developments will need to account for the particular needs of these regions.

\section{Conclusions}

\subsection{Research lessons and linkages}

Some researchers prefer to be 'lone wolves', bravely treading their research paths as intrepid explorers! These are usually the people who change the world, and they count many Nobel Prize Winners among them. However, in most cases, research is a shared experience, where teams of people find mutual benefit in working together and collaboratively exploring research questions. In this regard, the role of mentors and promoters for aspiring young researchers must be stressed. Fortunate is the young researcher who has such mentors and promoters who take interest in them. This is a vital role for more experienced and established researchers: just as good research uncovers more questions than it answers, so good researchers should leave behind more and better researchers than themselves!

We have indicated research lessons learnt, relevant to the specific research areas discussed, in the sections above. Key among these are the importance of a philosophical framework for successful research, the critical need to take the research 'out of the laboratory' and into the field to more fully understand the phenomena and governing factors and to develop realistic analytical tools and models, and the need to work with 'real' materials by way of concrete and not only pastes and mortars. However, other 'generic' and personal lessons have also been learnt, for example: 
- The importance of meticulous experimentation and observation; experimentation is not easy, it takes time, skill and patience to obtain good results in the laboratory; also, laboratory results can never be taken at face value ('never believe the data!'), but their validity and veracity must always be rigorously checked; if this is done from the outset, much heartache and trouble can be later avoided.

- The aim of good research is to try and understand what is going on, and also why or how. These are the 'big questions' of research. There is always an underlying mechanism, which yields only to intensive questioning and interrogation of the methods and the data. Simplistic data analysis often misses these essential points.

- Research is also about 'instinct': good researchers learn to trust those instincts, and always record their insights. This helps the 'bigger picture' to eventually emerge.

- Humility and a sense of one's own limitations are also important: it is true that others sometimes know more than you do, so ask them, learn from all of them, including the workers at the front face of implementing our ideas.

We strongly believe in the importance of active collaboration between academe on the one hand, and industry on the other, as well as bringing students and established researchers together in synergistic settings, with technology transfer appropriate to the industry-setting. We also believe that the first task of university-based researchers is the development of high-level human resources, from which the science and technology aspects follow.

\section{Closure}

The paper described benefits of collaborative research undertaken across a range of concrete problems in South Africa, over an extended time period. The benefits of such collaboration, especially where research funding is limited, are that a broader range of problems can be tackled, and resources can be better utilised. Consequently, South African concrete researchers have made and continue to make important contributions to cement and concrete science and engineering, locally and internationally.

The research areas outlined in the paper still represent rich possibilities for further work. Concrete is a continually developing material, and huge challenges remain with its use going into the future; importantly, research is needed in the local context to give confidence in its use since it comprises highly localised materials. Collaborative arrangements depend strongly on the willingness and collegiality of the collaborators, and this needs to be established for each new cohort of researchers.

One further point must be mentioned: at institutes of higher learning such as universities, research should have as its main objective, the development of highlevel human resources for society, the country, and for the relevant industries. Thus, our work has always been motivated primarily by the need for development of human intellectual capacity to strengthen the concrete construction sector in South 
Africa, and its contribution to social development. Of course, good research will also yield useful new knowledge and applications, which should have a strong impact on local practice, and in the context of concrete, help to improve the sustainability and durability of concrete infrastructure. This has always been our aim. We look forward to expanding these activities in the future to continue contributing to human development and local and internationally relevant research.

\section{Acknowledgements}

The work reported above would not have been possible without the involvement, over many years, of excellent research students, many of whom have gone on to establish strong research programmes in their own Institutions. We also acknowledge the input of our industrial collaborators.

\section{References}

[1] Mills, R.H.: Creep and shrinkage of concrete containing mixtures of Portland cement and high-magnesia blastfurnace slag, The Civil Engineer in in South Africa, vol. I I, no. I, ( 1969), Pp. I- I I.

[2] Oberholster, R. E.:Alkali Reactivity of Siliceous Rock Aggregates: Diagnosis of the Reaction, Testing of Cement and Aggregate and Prescription of Preventative Measures, Alkali in Concrete, Research and Practice, Copenhagen, Danish Concrete Association, (1983) pp. 4I 9-433.

[3] Blight, G.E.,Alexander, M.G.:Alkali-aggregate reaction and structural damage to concrete - Engineering assessment, repair and management, CRC Press, Taylor Francis Group, London, (20I I).

[4] Ballim, Y., Alexander, M.G.: Guiding principles in developing the South African approach to durability index testing of concrete. 6th International Conference on the Durability of Concrete Structures, University of Leeds, Leeds, UK, (2018).

[5] Alexander, M.G., Ballim, Y.: Contributions to research development in concrete in South Africa a 30-year collaborative venture. 3rd R.N. Raikar International Conference and 'Gettu - Kodur' International Symposium, Mumbai, Indian Chapter, American Concrete Institute. (2018) 10 pp.

[6] Alexander, M.G., Beushausen, H.: Experiences and challenges in concrete durability research at the University of Cape Town - a 20-year view. Scrivener and EPFL Anniversary Conference, Lausanne, 4 Pp, (2018).

[7] Alexander, M.G., Ballim, Y.; Experiences with durability testing of concrete: a suggested framework incorporating index parameters and results from accelerated durability tests. Proc. 3rd Canadian Symp. on Cement and Concrete, Ottawa, Nat. Res. Council, Ottawa, Canada, (1993) pp 248-263.

[8] Alexander, M.G., Mackechnie, J.R., Ballim, Y.: Guide to the use of durability indexes for achieving durability in concrete structures. Research Monograph No 2, Department of Civil Engineering, University of Cape Town, (1999) 35 pp.

[9] Alexander, M.G., Mackechnie, J.R., Ballim,Y. Chapter, Materials Science of Concrete. Use of durability indexes to achieve durable cover concrete in reinforced concrete structures. Vol. VI, Ed. J. P. Skalny and S. Mindess, American Ceramic Society, (200I) pP 483 - 5 II. 
[10] Alexander, M.G., Ballim, Y., Stanish, K.: A framework for use of durability indexes in performancebased design and specifications for reinforced concrete structures. Materials \& Structures, Vol. 4I, No. 5, pp. 921 -936. (2008).

[II] Gouws, S.M.,Alexander, M.G., Maritz, G.: Use of durability index tests for the assessment and control of concrete quality on site. Concrete Beton, No. 98, (200I) pp 5-16.

[12] SANS-300I-CO3-I, 20I5. Civil Engineering Test Methods: Part CO3-I: Concrete Durability Index Testing - Preparation of test specimens, South African Bureau of Standards - Standards Division, Pretoria, South Africa, ISBN 978-0-626-32799-6. (2015).

[13] SANS-300I-CO3-2, 20I5. Civil Engineering Test Methods: Part CO3-2: Concrete Durability Index Testing - Oxygen permeability test, South African Bureau of Standards - Standards Division, Pretoria, South Africa, ISBN 978-0-626-32800-9. (2015).

[14] SANS-300I-CO3-3, 2015. Civil Engineering Test Methods: Part CO3-3: Concrete Durability Index Testing - Chloride conductivity test, South African Bureau of Standards - Standards Division, Pretoria, South Africa, ISBN 978-0-626-3280 I-6. (20I5).

[15] Starck. S., Beushausen, H., Alexander, M., Torrent, R.: Correlation between in-situ and laboratorybased concrete permeability measurements, Materials and Structures, (20I7), 50-I 17.

[16] Beushausen, H., Torrent, R., Alexander, M.G.: Performance-based approaches for concrete durability: state of the art and future research needs. CCR.Accepted, (2019).

[17] Nganga, G., Alexander, M.G.: Practical application of on-site durability testing for RC structures. ACCTA Conference (International Conference on Advances in Cement and Concrete Technology in Africa 2013), Emperor's Palace, Gauteng, (20I3).

[18] Otieno, M.B., Alexander, M.G., Beushausen, H.D.: Corrosion in cracked and uncracked concrete influence of crack width, concrete quality and crack re-opening, Magazine of Concrete Research,Vol. 62 (2010) 6, pp. 393-404.

[19] Otieno, M.B.: Corrosion propagation in cracked and uncracked concrete, Masters dissertation, Department of Civil Engineering, University of Cape Town, (2008).

[20] Otieno, M., Alexander, M., Beushausen, H.: Acceleration of steel corrosion in concrete by cyclic wetting and drying: effect of drying duration and concrete quality. Materials \& Structures, pp. 52-50, 2019.

[2I] Ballim,Y., Reid, J.C., Kemp,A.R. Deflection of RC beams under simultaneous load and steel corrosion. Magazine of Concrete Research, 53 (200I) 3, pp. I7I-I8I

[22] Cabrera, J.G., Ghoddousi, P.: The effect of reinforcement corrosion on the strength of the steel/ concrete bond. In: Proceedings of the Conference on Bond in Concrete Latvia, I992, CEB, p. I I-24 [chapter 10].

[23] Gibbon, G.J., Ballim, Y., Grieve, G.R.H.: A low-cost, computer controlled adiabatic calorimeter for determining the heat of hydration of concrete. Technical Note. Journal of Testing and Evaluation, American Society for Testing and Materials, 25 (1997) 2, pp. 26I-266.

[24] Ballim,Y., Graham, P.C.: Early-age heat evolution of clinker cements in relation to microstructure and composition: implications for temperature development in large concrete elements. Cement and Concrete Composites, 26 (2004), pp. 4I7-426.

[25] Ballim,Y., Graham, P.C.: A maturity approach to the rate of heat evolution in concrete. Magazine of Concrete Research, 55 (2003) 3, pp. 249-256. 
[26] Alexander, M.G., Goyns, A., Fourie, C.W.: Experiences with a full-scale experimental sewer made with CAC and other cementitious binders in Virginia, South Africa. Proceedings, Calcium Aluminate Cements, The Centenary Conference, (2008), Bracknell: IHS BRE Press, pp. 279-292.

[27] Alexander, M.G., Fourie, C.W.: Performance of sewer pipe concrete mixtures with Portland and calcium aluminate cements subject to mineral and biogenic acid attack. Materials and Structures, Vol. 44(I), (20II) Pp. 313-330.

[28] Fourie, C.W., Alexander, M.G.:Acid resistant concrete sewer pipes. Proceedings of the International RILEM TC-2I I PAE Final Conference, Toulouse, (2009), Bagneux: RILEM Publications S.A.R.L., 2009, Pp. 408-4I8.

[29] Kiliswa, M.W., Scrivener, K., Alexander, M.G.: The microstructure and corrosion rate of Portland cement and calcium aluminate cement-based concrete mixtures in outfall sewers: A comparative study. Cement \& Concrete Research, (2019).

[30] Kiliswa, M.: Composition and microstructure of concrete mixtures subjected to biogenic acid corrosion and their role in corrosion prediction of concrete outfall sewers. PhD thesis, University of Cape Town, 2016.

Further references and materials can be found on the following website: www.comsiru.uct.ac.za 